\title{
Behaviour of Strengthened Flat Slab with Opening at Edge Column under Punching Shear Strength
}

\author{
Waleed Abdallah Ali, Eman Selemn Mohamed
}

\begin{abstract}
Flat slab system is widely used because of its architectural flexibility Punching is one of the major and critical problems in flat slab especially for the edge column. There are many traditional ways to increase the punching shear strength of concrete slabs like increasing the slab thickness or column dimensions which is against the architectural desire Using FRP strengthening for the flat slabs against punching shear can be considered as a new application. Sometimes an opening is needed to be punched through existing slabs to install cables, elevators and ventilation systems, etc. This causes weakening due to the cutting of concrete and reinforcing steel and also increases the punching problems especially if the opening beside the edge columns. This research is aimed to evaluate the effects of strengthening with Glass Fiber Reinforced Polymer (GFRP) on the punching shear behaviour of flat slab with an opening varying in location with respect to the edge column. Bearing capacity, deflection, ductility, energy absorption and stiffness obtained from the tested slabs are compared to the control specimen, which was without opening and strengthening. It is observed that, the punching shear capacities of the strengthened specimens significantly increased compared to control specimen. Creating openings in flat slab beside the edge column should be approached with great caution and avoided if possible because of its bad effects. In case of openings are of extreme necessity, it is recommended to be created in the front of the edge column not in the side.
\end{abstract}

Keywords : Flat Slab, Punching Shear, Edge Column, Opening, Glass fiber.

\section{INTRODUCTION}

Flat slabs are one of the most popular slab systems that are usually preferred by architectures for its advantages, which are well known. On the other hand, flat slabs are vulnerable to brittle failure mode of punching shear failure, which is the main drawback of this system. Punching failure is undesirable and they do not allow an overall yield mechanism to develop before punching, by [1]. Punching shear strength of flat slabs can be improved by providing drop panels or

Revised Manuscript Received on February 05, 2020.

* Correspondence Author

Waleed Abdallah Ali*, Assistant Prof. Faculty of Engineering, Civil

Department, Helwan University, Cairo, Egypt. Email: Waleed_abdallah@m-eng.helwan.edu.eg

Eman Seleman Mohamed, M. Sc. Student, Faculty of Engineering, Civil Department, Helwan University, Cairo, Egypt. E-mail: emanseleman254@yahoo.com

(C) The Authors. Published by Blue Eyes Intelligence Engineering and Sciences Publication (BEIESP). This is an open access article under the CC BY-NC-ND license (http://creativecommons.org/licenses/by-nc-nd/4.0/) column capitals, which may be impractical for architectural reasons. Creating openings in the slab after construction, by cutting concrete and reinforcing steel leads to less resistance to the stresses, so it is needed to be strengthened. The effect of opening depends on its locations within the column strips and/or the middle strips. The preferred location of the opening is away from the columns to avoid punching shear failure. Sometimes functional requirements often cause them to be located close to the columns, so the increase of punching shear resistance for RC slab column connections may be needed. The strengthening against punching shear by using traditional methods (steel plates, steel stirrups, or increasing concrete dimension) was studied by [2], [3]. A. M. Abdelrahman et. al, [4] studied the effect of using steel fibers in the mix on the punching shear behavior of internal column-slab connection. The study provided that the higher the steel fiber ratio was the higher the ultimate load carrying capacity of the specimens. N.Z. Hassan et. al, [5] studied the effect of using steel band strips to enhance the punching shear strength of flat slab. They concluded that shear bands distributed over the critical punching shear zone provide an increasing the punching shear capacity, ductility and energy absorption. C. Dulude et. al,[6] studied the effect of using glass fiber-reinforced polymer bars for punching shear behavior of flat slab. All the tested slab prototypes showed punching shear failure and similar crack patterns, regardless of the reinforcement type and ratio. The slab prototypes with low reinforcement ratios showed some ductile behavior and large deformation before the punching shear failure. H. Eid et. al, [7] studied the effect of openings on the punching shear strength of post-tensioned flat slabs supported on square columns. They provide the relation between the punching effective perimeter and the punching strength is nearly linear for post-tensioned slabs. N.K. Oukaili and T.S. Salman [8] studied the effect of openings on the punching shear behavior of the slab-column connections. They provide that Slabs with openings have maximum crack width larger than what observed in the reference slab during the same loading stage. C. Durucan and Ö. Anil [9], also A.S. Alfatlawi and H.A. Abed [10] carried out a research to study CFRP strengthening of concrete slabs with and without openings. They found that Using CFRP strips in two way reinforced concrete slabs with openings had a significant effect on the ultimate strength and deflection of testing slabs. G.I Khaleel et. al, [11] carried out a research to explore to the efficiency of using fiber reinforced polymers (FRP) systems to strengthen the slab-column connections subjected to punching shear.

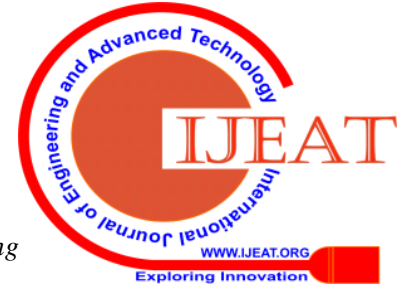


They found that CFRP intertwined stirrups were the best strengthening for this study. K.H. Tan [12] studied strengthening of flat plates with an opening using FRP systems. He provides that the FRP system could successfully restore the punching shear strength. M.G. Elgendy [13] performed an experimental program to study punching shear behavior of slab-column edge connections, reinforced with fiber reinforced polymer (FRP) composite bars. He noted that the punching failure was characterized by a drastic drop in the vertical load when the column along with a conical portion of the slab punched through the remainder of the slab. Few studies concerns with using the FRP strengthening systems in opening of flat slab at edge column, so this present study aims to evaluate the using of FRP materials to increase the punching shear resistance of flat slab with an opening created at the edge column.

\section{EXPERIMENTAL PROGRAM}

\section{A. Experimental program matrix}

In the scope of the research program, a total of eleven specimens of edge column-flat slab connection was prepared and tested with fixed dimensions (1700x1000x160mm) and square edge column (200x200mm) with $400 \mathrm{~mm}$ total height extended outside the top side of the slab as shown in Figure1. The specimens were reinforced with mesh of $6 \varnothing 16 / \mathrm{m}$ at the tension side and $6 \varnothing 10 / \mathrm{m}$ at the compression side. The area of tension reinforcement calculated to fail in pure punching shear, not to both flexure and punching. The column reinforced with $4 \varnothing 16$ longitudinal high tensile steel and normal mild $10 \varnothing 8 / \mathrm{m}$ as stirrups, as shown in Figure2.

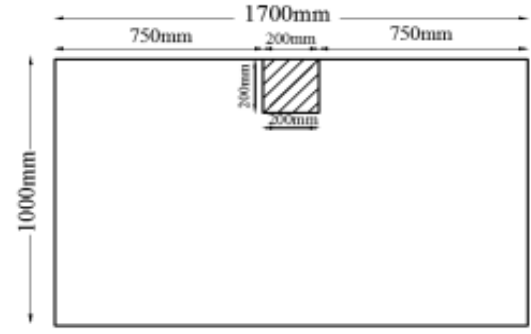

Figure

Typical dimensions of specimens
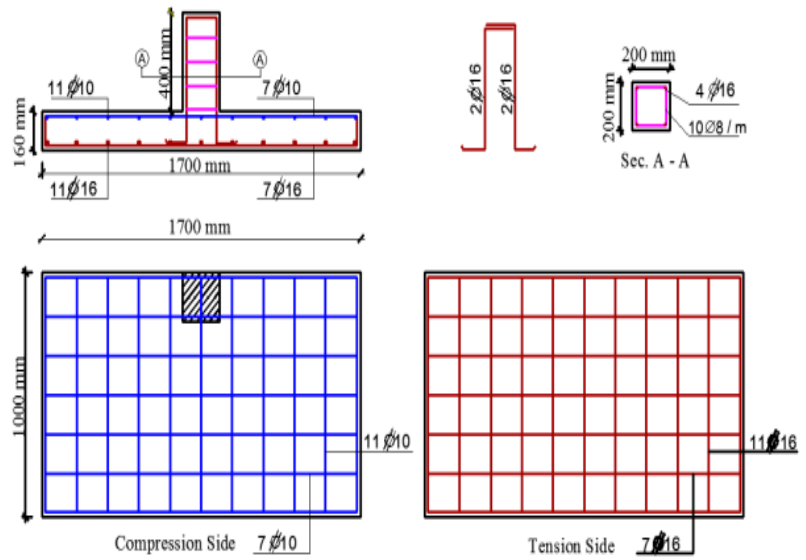

Figure 2. Typical reinforcement details of specimens

The experimental program was divided into two groups, which have GFRP strengthened specimens after creating an opening in addition to the control specimen without opening and strengthening. The first group, (A) investigates the effect of cutting an opening (200x200 mm) beside the edge column and strengthening with GFRP as shown in Figure3. The second group, (B) studies the effect of creating an opening (200x200 mm) in front of the edge column and strengthening with GFRP as shown in Figure4. Each of the two groups has four specimens strengthened with variable width GFRP sheets equal to $(0.0 \mathrm{~d}, 1.0 \mathrm{~d}, 1.50 \mathrm{~d}, 2.0 \mathrm{~d})$ from the column at the tension side only of the slab in additional to another one specimen strengthened with (2.0d) width GFRP sheets from the column at the tension and compression side of the slab, where $d$ is the slab depth. The details of testing specimens are
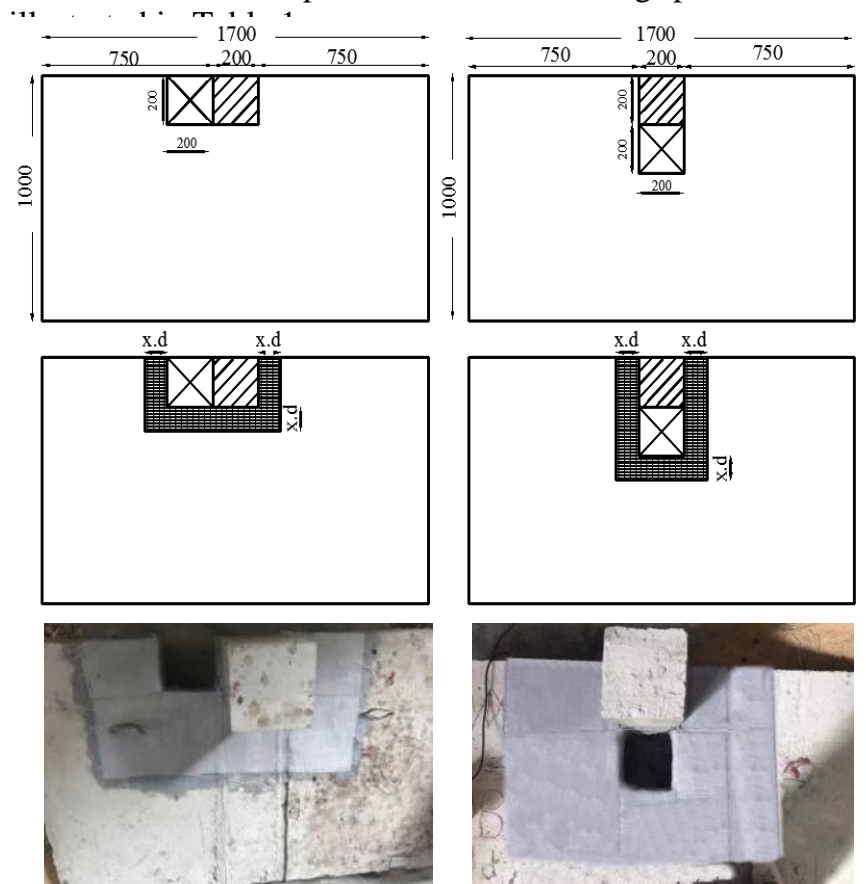

Figure3.Specimen of group A Figure4.Specimen of group B

Table 1. Specimens details.

\begin{tabular}{|c|c|c|c|}
\hline $\begin{array}{l}\text { Group } \\
\text { No. }\end{array}$ & $\begin{array}{c}\text { Specimens } \\
\text { Name }\end{array}$ & $\begin{array}{l}\text { Opening } \\
\text { Location }\end{array}$ & $\begin{array}{l}\text { GFRP sheet } \\
\text { width }\end{array}$ \\
\hline $\begin{array}{l}\text { Control } \\
\text { Specimen }\end{array}$ & $(\mathrm{S}-\mathrm{C})$ & Without Opening & Without Fiber \\
\hline \multirow{5}{*}{ A } & $\begin{array}{l}\text { S-A-O-S } \\
(0.0 \mathrm{~d})\end{array}$ & Beside the column & Without Fiber \\
\hline & $\begin{array}{l}\text { S-A-O-S } \\
(1.0 \mathrm{~d})\end{array}$ & Beside the column & $\begin{array}{c}1.0 \mathrm{~d} \\
(140 \mathrm{~mm})\end{array}$ \\
\hline & $\begin{array}{l}\text { S-A-O-S } \\
(1.5 \mathrm{~d}) \\
\end{array}$ & Beside the column & $\begin{array}{c}1.5 \mathrm{~d} \\
(210 \mathrm{~mm})\end{array}$ \\
\hline & $\begin{array}{l}\text { S-A-O-S } \\
(2.0 \mathrm{~d})\end{array}$ & Beside the column & $\begin{array}{c}2.0 \mathrm{~d} \\
(280 \mathrm{~mm})\end{array}$ \\
\hline & $\begin{array}{c}\text { S-A-O-S } \\
\left(2.0 d^{*}\right)\end{array}$ & Beside the column & $\begin{array}{c}2.0 \mathrm{~d}^{*}(280 \mathrm{~mm}) \\
\mathrm{T} \& \mathrm{~B} \\
\end{array}$ \\
\hline \multirow{5}{*}{ B } & $\begin{array}{l}\text { S-B-O-F } \\
(0.0 \mathrm{~d})\end{array}$ & Front of the column & Without Fiber \\
\hline & $\begin{array}{l}\text { S-B-O-F } \\
(1.0 \mathrm{~d})\end{array}$ & Front of the column & $\begin{array}{c}1.0 \mathrm{~d} \\
(140 \mathrm{~mm})\end{array}$ \\
\hline & $\begin{array}{l}\text { S-B-O-F } \\
(1.5 \mathrm{~d}) \\
\end{array}$ & Front of the column & $\begin{array}{c}1.5 \mathrm{~d} \\
(210 \mathrm{~mm})\end{array}$ \\
\hline & $\begin{array}{l}\text { S-B-O-F } \\
(2.0 \mathrm{~d}) \\
\end{array}$ & Front of the column & $\begin{array}{c}2.0 \mathrm{~d} \\
(280 \mathrm{~mm}) \\
\end{array}$ \\
\hline & $\begin{array}{l}\text { S-B-O-F } \\
(2.0 \mathrm{~d} *)\end{array}$ & Front of the column & $\begin{array}{c}2.0 \mathrm{~d} *(280 \mathrm{~mm}) \\
\mathrm{T} \& \mathrm{~B} \\
\end{array}$ \\
\hline
\end{tabular}

Noted that:

(S-A-O-S (x. d)): [Slab - group A or B -Opening-Side or Front opening position-Strengthening width] 


\section{B. Material properties}

The materials used in fabricating the test specimens' mixtures were matched with ECP 203 limits. The process of manufacturing was closely similar to the common way of the concrete manufacture in Egypt uses ordinary Portland cement, sand, crushed dolomite, and water. The average characteristic concrete strength of the tested standard cubes after 28 days of casting was $30 \mathrm{MPa}$. The properties of reinforcement used the experimental work are indicated in table 2 .

Table 2. Properties of reinforcement used in the experimental work.

\begin{tabular}{|c|c|c|c|}
\hline Properties & $\Phi 8$ & $\Phi 10$ & $\Phi 16$ \\
\hline Yield stress $(\mathrm{MPa})$ & 280 & 515.4 & 408.5 \\
\hline Ultimate Stress $(\mathrm{MPa})$ & 388 & 666.2 & 685.6 \\
\hline Actual Area $\left(\mathrm{mm}^{2}\right)$ & 50 & 78 & 201 \\
\hline
\end{tabular}

Glass Fiber Reinforced Polymer (GFRP) sheets used in strengthening is SikaWarp-430G which has a two-directional woven glass fiber fabric designed for installation using the dry or a wet application process, as shown in Figure 5. The properties of GFRP used in this work given by the manufacturer are indicated in Table 3. Thixotropic impregnation resin/ adhesive were used to adhere the Glass fiber reinforcing fabric to tested slabs. The used Epoxy was Sikadur -330 which is a product of Sika Construction Company as well, .(sikadur 330 which Consists of two components (A , B) of epoxy mixed with ratio 4:1 respectively

Table 3 Properties of glass fiber sheets.

\begin{tabular}{|l|c|}
\hline Dry fibre Density & $2.56 \mathrm{~g} / \mathrm{cm}^{2}$ \\
\hline Area Density & $430 \mathrm{~g} / \mathrm{m}^{2}$ \\
\hline Dry fibre tensile strength & $2500 \mathrm{~N} / \mathrm{mm}^{2}$ \\
\hline Dry fibre modulus of elasticity in tension & $72000 \mathrm{~N} / \mathrm{mm}^{2}$ \\
\hline Dry fibre Thickness & $0.168 \mathrm{~mm}$ \\
\hline
\end{tabular}

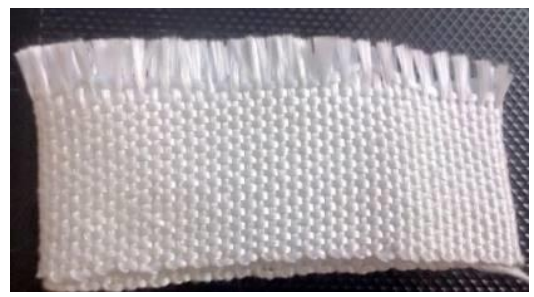

Figure 5. Two-Directional glass fiber sheets

\section{Test set-up}

A very rigid steel frame consisting of horizontal and vertical I-sections was used as a base to support slab specimens. The slab specimens were mounted in a horizontal position inside the steel frame to serve as a simple line support along the three edges of the slabs, where the slab edge at the edge column side is free. The specimens were tested under vertical load using hydraulic jack $1000 \mathrm{KN}$ capacity, which was applied up to slab failure. A rigid steel I beams was used to transverse the applied single concentrated load directly to the axis of the edge column using a rigid steel plate. The load was applied in successive increments and the loading speed was kept constant during the test of all specimens. Test setup and instrumentation details are given in Figure 6. The tests were carried out in the reinforced concrete laboratory of the Faculty of Engineering, El-Mataria, Helwan University. Deformation profiles of the tested slabs and the deflection were measured using electronic displacement transducers (LVDTs), which were fixed in four different positions on the tension side of the specimen, as shown in Figure7. The development of cracks and deflection were observed during loading and recorded after each increment till failure.
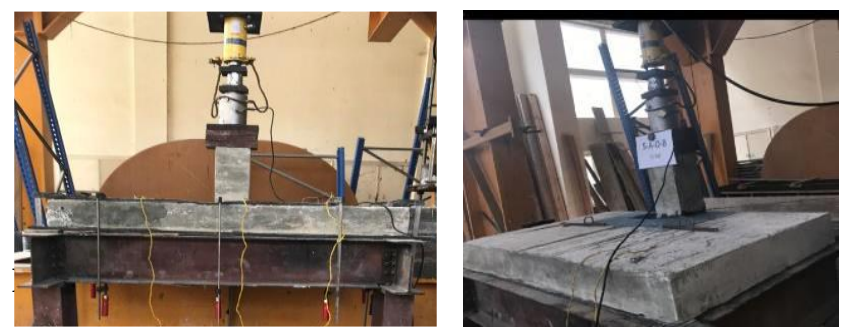

Figure 6. Test set-up

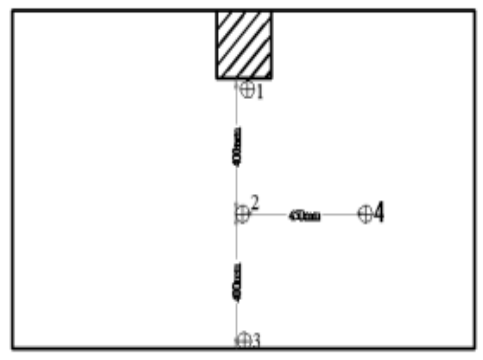

Figure

locations

7. LVDTs

\section{EXPERIMENTAL RESULTS AND DISCUSSION}

The load-displacement relations, crack pattern, stiffness, ductility and energy absorption of the test specimens are obtained from the experimental study and presented comparatively. The obtained results were analyzed and discussed the effect of glass fiber width and the opening location on the behavior punching shear strength of the edge column- flat slab connection after strengthening with GFRP

\section{A. Effect of the opening location}

This parameter studied by testing 3 specimens without strengthening, control slab without opening, slab with opening beside the edge column and finally slab with opening in front of the edge column. ((S-C), (S-A-O-S (0.0d)), and (S-B-O-F (0.0d)). Location of the opening with respect to the edge column has a significant effect on the punching shear load capacities and the behavior of flat slab.

\section{Loads and crack pattern}

All the tested specimens were loaded under centric vertical load on the edge column and failed due to punching shear. The cracks appeared firstly around the column at the tension side of the slab. As the applied load increased, the cracks propagated and became wider. For the tested specimens, creating an opening at the edge column zone caused significant decreases in the first crack load by about $62 \%$ and $34 \%$ for side and front opening respectively in comparison with the control specimen as shown in Figure8.

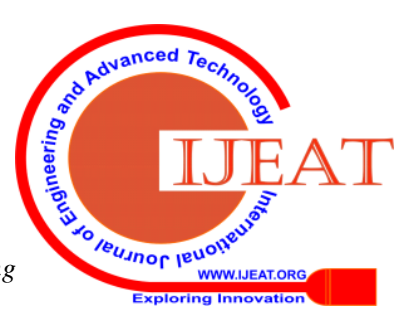


Also, the punching shear failure capacities of the test specimens are decreased by about $62 \%$ and $35 \%$ smaller than the control specimen for side and front opening respectively as shown in Figure 9.

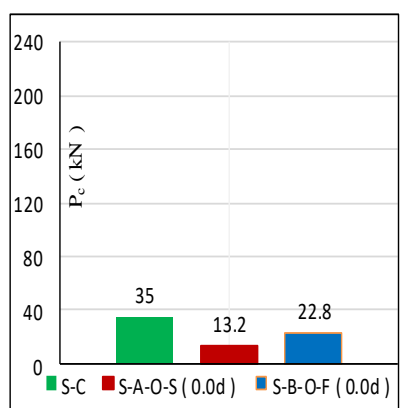

Figure 8. Cracking load

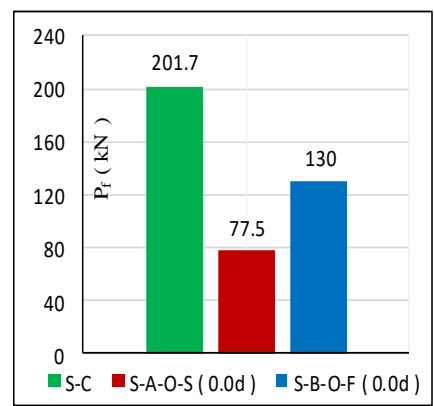

Figure 9. Failure load

\section{Load deflection relation}

For all tested specimens, the deflection values, measured at four different points (see Figure7.) and recorded at each load increment. The load-deflection relationships at the point (1) in front of the edge column are given in Figure 10. From the deformation profiles of the specimens, it is observed that, generally, creating an opening in the edge column zone increase the slab deflection compared to the control at the same loading level. However, comparing the load-deflection curves of the tested specimens, it can be seen that slab with opening beside the edge column has the minimum stiffness compared to the similar slab with an opening in the front of edge column, and this indicates that the position of opening has a significant effect on the behavior of flat slab deformation and capacity.

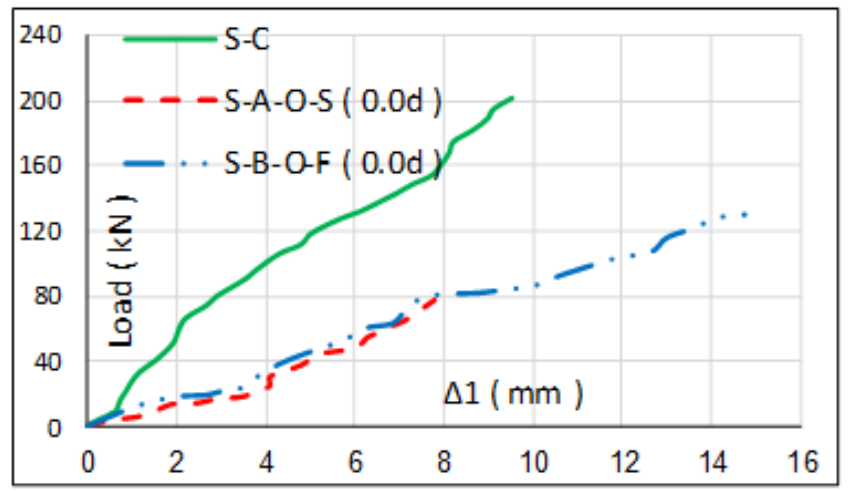

Figure 10. Load deflection curves for S-C, S-A-O-S (0.0d), S-B-O-F (0.0d).

\section{Stiffness}

The initial stiffness of the test specimens were calculated as $\left(\mathrm{K}_{\mathrm{i}}=\mathrm{P}_{\mathrm{cr}} / \Delta_{\mathrm{cr}}\right)$ using the slope of the linear zone of the curve before cracking as indicated in table 4 and Figure 11. From the initial stiffness values of the test specimens it is observed that creating openings and the openings location have a significant effect on the slab initial stiffness. Cutting an opening beside the edge column leads the further reduction of the initial stiffness of the specimens relative to the openings located in front of the same column. It was observed that the reduction in the stiffness was $22 \%$ and $8 \%$ for side and front opening location respectively compared to control specimen.
Table 4. Initial stiffness values.

\begin{tabular}{|c|c|c|c|c|c|}
\hline \multirow{2}{*}{$\begin{array}{c}\text { Specimen } \\
\text { Name }\end{array}$} & \multicolumn{2}{|c|}{ Cracking } & \multicolumn{2}{|c|}{ Failure } & Stiffness \\
\cline { 2 - 6 } & $\begin{array}{c}\Delta_{\mathrm{f}} \\
(\mathrm{mm})\end{array}$ & $\begin{array}{c}\mathrm{P}_{\mathrm{f}} \\
(\mathrm{kN})\end{array}$ & $\begin{array}{c}\Delta_{\mathrm{cr}} \\
(\mathrm{mm})\end{array}$ & $\begin{array}{c}\mathrm{P}_{\mathrm{cr}} \\
(\mathrm{kN})\end{array}$ & $\begin{array}{c}\mathrm{K}_{\mathrm{i}}=\mathrm{P}_{\mathrm{cr}} \\
/ \Delta_{\mathrm{cr}} \\
\mathrm{kN} / \mathrm{mm}\end{array}$ \\
\hline S-C & 9.16 & 9.53 & 201.7 & 3.82 & 35 \\
\hline S-A-O-S(0.0d) & 7.13 & 7.79 & 77.5 & 1.85 & 13.2 \\
\hline S-B-O-F(0.0d) & 8.5 & 14.7 & 130 & 2.68 & 22.8 \\
\hline
\end{tabular}

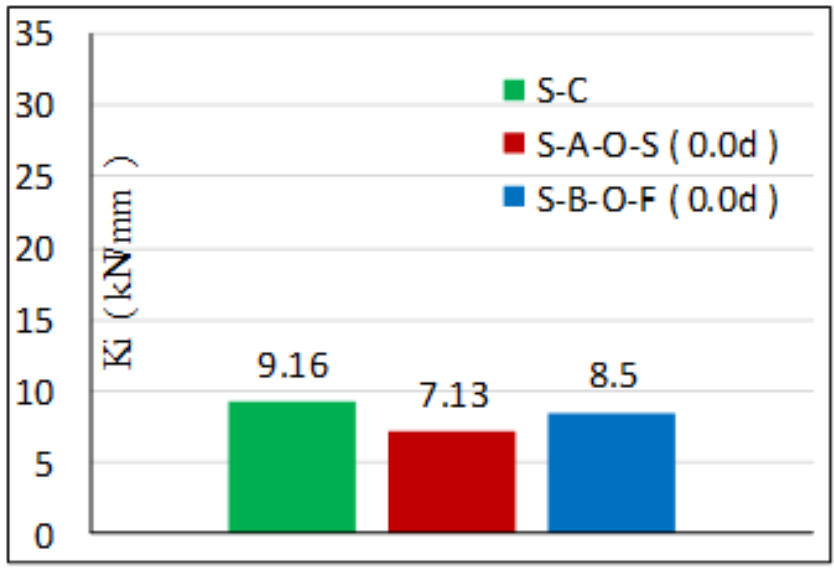

Figure 11. Initial Stiffness Values

\section{Absorbed energy}

The energy absorption, which based on the displacement was calculated as the area under the load-deflection curve and shown in Figure 12. From the tested specimens, creating an opening in the edge column zone has decreased the energy absorption by about $70 \%$ and $15 \%$ for side and front opening location respectively compared to control specimen.

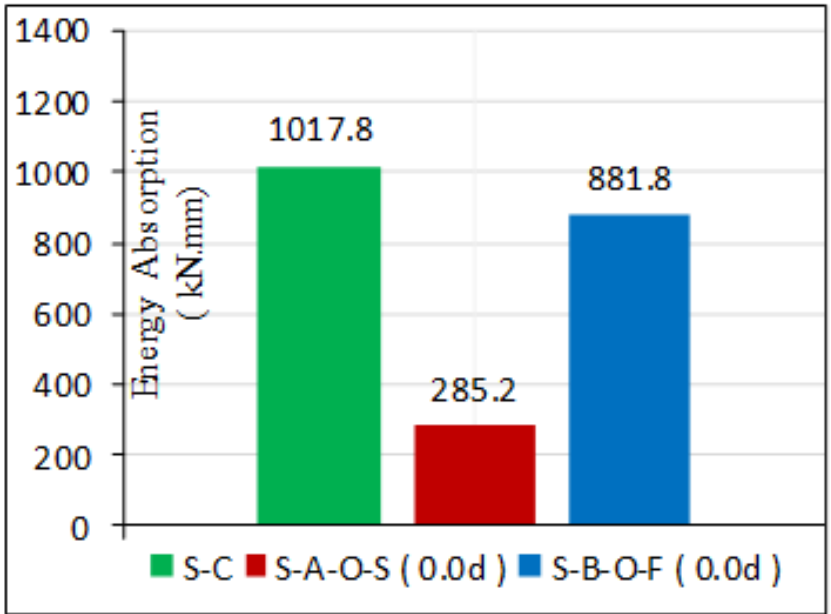

Figure 12. Energy Absorption Values

\section{B. Effect of the opening location and GFRP} strengthening area for group $\mathbf{A}, \mathbf{B}$.

This parameter studied the effect of two different opening locations groups $(\mathrm{A}, \mathrm{B})$ as indicated in Table 1 with several GFRP strengthening widths on the behavior of flat slab punching shear strength. Opening location and strengthening width have a significant effect on the punching shear load capacities and the behavior of flat slab.

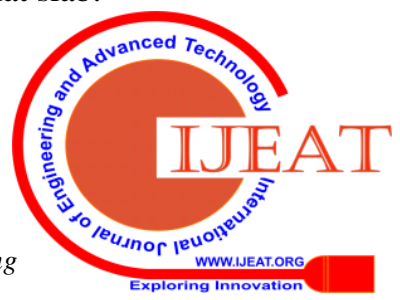




\section{Loads and crack pattern}

The first crack for all slabs was initiated at early stage of loading and then, as the applied load increased, the cracks propagated and became wider and new cracks appeared as well as shown Figure 13. The cracking load value changed by changing the opening location and strengthening width as shown in Figure 14. The strengthening of the specimen caused a significant increase in the first crack and the failure load. It is noted that, slabs with opening created beside the edge columns has faster and bigger cracks than others where the opening created in the front of the column.. From the tested specimens, it's noted that as the strengthening width increase the punching shear capacity increase. For the tested specimens in the group (A), the failure load increased by about $16 \%, 23 \%, 29 \%$ and $48 \%$ in case of $1.0 \mathrm{~d}, 1.5 \mathrm{~d}, 2 \mathrm{~d}$ and $2 \mathrm{~d}^{*}$ strengthening width respectively compared to slab with 15. The increased failure loads ratios for the tested specimens $1.0 \mathrm{~d}, 1.5 \mathrm{~d}, 2 \mathrm{~d}$ and $2 \mathrm{~d}^{*}$ strengthening width respectively compared to slab with front opening and without strengthening. Generally from this study, it's noted that the location of the opening in front of the edge column with and without strengthening has the maximum values of slab capacities in all studied cases. The punching shear failure load for group (B) specimens increased by about 67\%, 61\%, $63 \%, 75 \%$ and $70 \%$ in case of $1.0 \mathrm{~d}, 1.5 \mathrm{~d}, 2 \mathrm{~d}$ and $2 \mathrm{~d}^{*}$ strengthening width respectively compared to the same specimens in the group (A)
(S.A-O-S (0.0d))

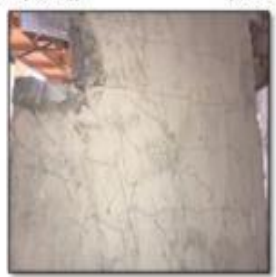

(S-A-0-S(2.0d))

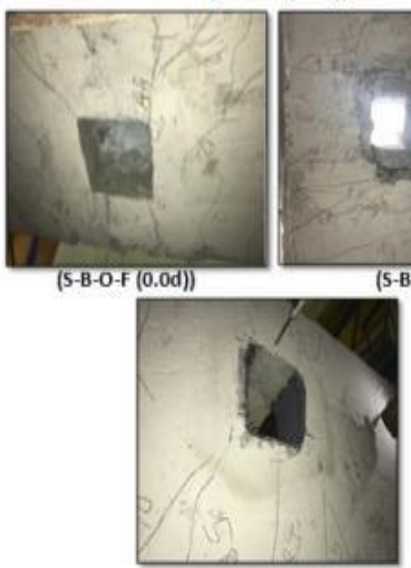

(S-B-0-F (1.5d))

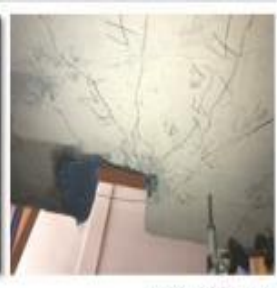

(S-A-0-S (1.5d))
(S-A-O-S (1.0d))

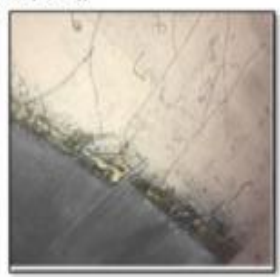

$(5-A-0-5(2.0 d))$

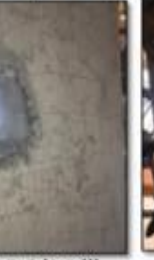

-B-O-F (1.0d))

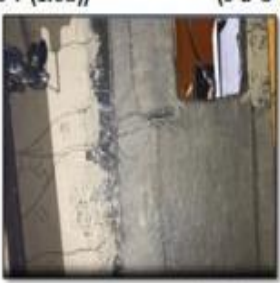

(s-8-0-F(2.0d))
Figure 13. Crack Patterns for Studied Specimens side opening and without strengthening as shown in Figure in the group (B) were $12 \%, 20 \%, 35 \%$ and $50 \%$ in case of
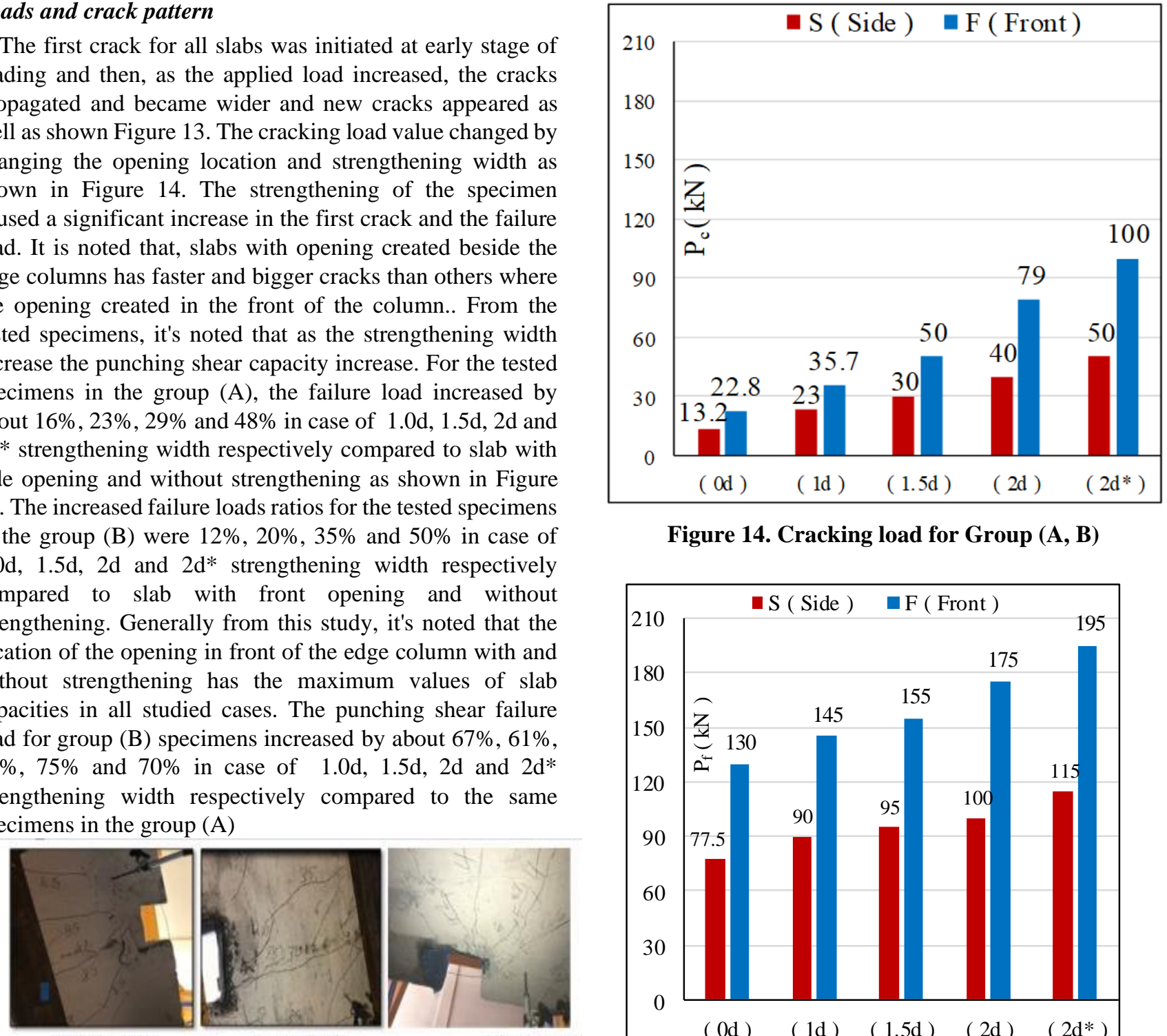

Figure 14. Cracking load for Group (A, B)

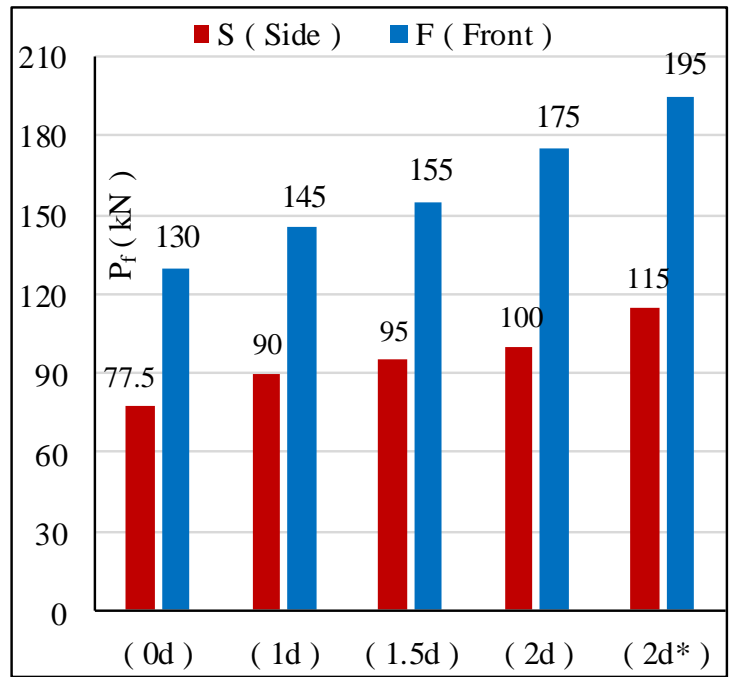

Figure 15. Failure load for Group (A, B).

\section{Load deflection relation}

The deflection value for all tested specimens was recorded at each load increment. Load-deflection relationship comparison between all strengthened specimens for the both groups (A and B) is shown in Figure16. Although the ultimate loads of the strengthened specimens were different, the load-deflection relationships of these specimens were moderately similar. The curve initially had a steep behavior till reaching the cracking load, and then started to be more curved until reaching the ultimate load of the slab. Creating opening beside the edge column for all slabs in group (A) has the highest values of deflection compared to the case of creating a front opening in the slabs of group (B) at the same load level. However, comparing the load-deflection curves of group (A) and (B), it can be seen that specimens in the group (A) have the minimum stiffness compared to the similar specimens in the group (B), and this indicates that in the case of openings are extreme necessity, it is recommended to be created in the front of the column not in the side.

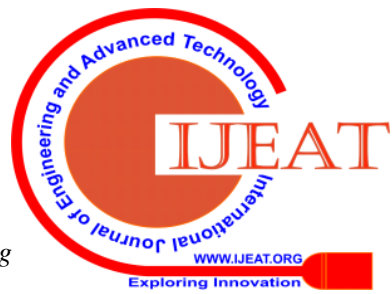


In the two cases front and side opening, using GFRP strengthening sheets enhanced the behavior of strengthening slabs, the further the GFRP sheet width increased the further the strength increased, especially the specimens were strengthened from tension and compression side in comparison to the control specimen for each group.

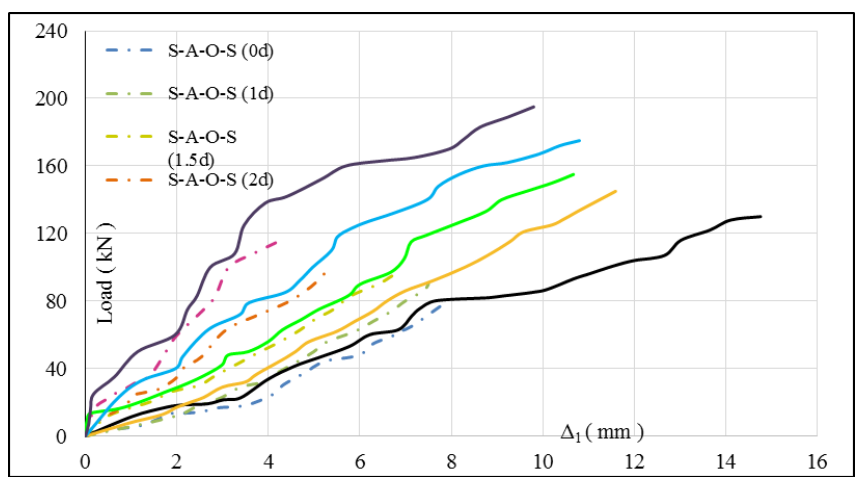

Figure 16. Deflection-Load Curve for groups (A, B)

\section{Stiffness}

From the load deflection curves of the tested specimens the un-cracked stiffness Ki (initial stiffness) was calculated as $(\mathrm{Ki}=\mathrm{Pcr} / \Delta \mathrm{cr})$. The value of the loads and deflections of the studied specimens at the crack and failure stages is shown in Table. 5. Form the shown values, it observed that the stiffness for the tested specimens in group (B), slabs with front opening increased by $19 \%, 9 \%, 10 \%, 5 \%$ and $12 \%$ for $0 \mathrm{~d}$, $1.0 \mathrm{~d}, 1.5 \mathrm{~d}, 2 \mathrm{~d}$ and $2 \mathrm{~d} *$ respectively compared with the same specimens in the group (A), slabs with side opening as shown in Figure17.

Table 5. Stiffness Values for Group A and Group B.

\begin{tabular}{|c|c|c|c|c|c|}
\hline \multirow{2}{*}{$\begin{array}{c}\text { Specimen } \\
\text { Name }\end{array}$} & \multicolumn{2}{|c|}{ Cracking } & \multicolumn{2}{|c|}{ Failure } & Stiffness \\
\cline { 2 - 6 } & $\begin{array}{c}\Delta_{\mathrm{f}} \\
(\mathrm{mm})\end{array}$ & $\begin{array}{c}\mathrm{P}_{\mathrm{f}} \\
(\mathrm{kN})\end{array}$ & $\begin{array}{c}\Delta_{\mathrm{cr}} \\
(\mathrm{mm})\end{array}$ & $\begin{array}{c}\mathrm{P}_{\mathrm{cr}} \\
(\mathrm{kN})\end{array}$ & $\begin{array}{c}\mathrm{K}_{\mathrm{i}}=\mathrm{P}_{\mathrm{cr}} \\
/ \Delta_{\mathrm{cr}} \\
\mathrm{kN} / \mathrm{mm}\end{array}$ \\
\hline S-A-O-S (0.0d) & 7.13 & 7.79 & 77.5 & 1.85 & 13.2 \\
\hline S-A-O-S(1.0d) & 8.87 & 7.59 & 90 & 2.59 & 23 \\
\hline S-A-O-S(1.5d) & 12.09 & 6.71 & 95 & 2.48 & 30 \\
\hline S-A-O-S(2.0d) & 18.8 & 5.34 & 100 & 2.12 & 40 \\
\hline S-A-O-S (2.0d*) & 28.4 & 3.87 & 115 & 1.97 & 50 \\
\hline S-B-O-F(0.0d ) & 8.5 & 14.7 & 130 & 2.68 & 22.8 \\
\hline S-B-O-F(1.0d ) & 9.67 & 11.6 & 145 & 3.69 & 35.7 \\
\hline S-B-O-F(1.5d) & 13.4 & 11.4 & 155 & 3.71 & 50 \\
\hline S-B-O-F(2.0d ) & 19.8 & 11.2 & 175 & 3.98 & 79 \\
\hline S-B-O-F(2.0d*) & 31.94 & 10.2 & 195 & 3.13 & 100 \\
\hline
\end{tabular}

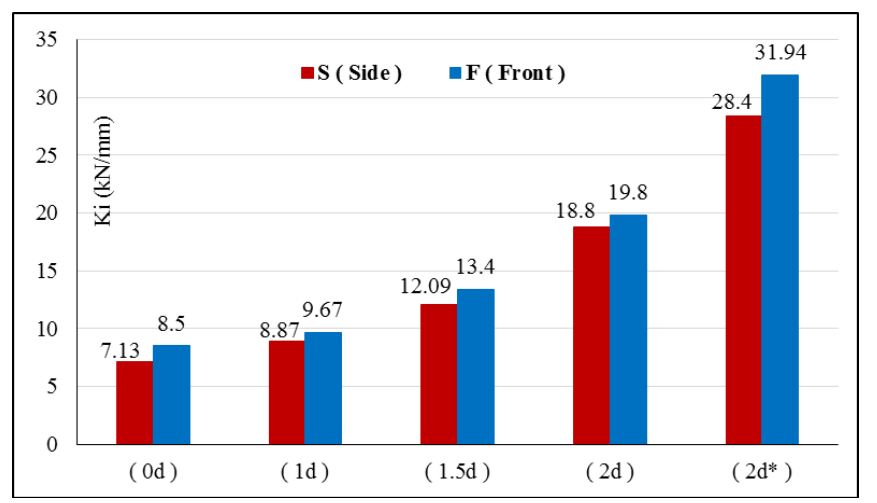

Figure 17. Initial Stiffness for Group (A, B).

\section{Ductility index and energy absorption}

Ductility was calculated as the difference between deflection at the failure and cracking load divided to deflection at cracking load, (D.I $=\frac{\Delta_{\mathrm{f}}-\Delta_{\mathrm{er}}}{\Delta_{\mathrm{er}}} \quad$ ) for the studied specimens. The calculated ductilities of group (B) with front opening increased by about 40\%, 5\%, 21\%, 24\% and $130 \%$ for $0 \mathrm{~d}, 1.0 \mathrm{~d}, 1.5 \mathrm{~d}, 2 \mathrm{~d}$ and $2 \mathrm{~d}^{*}$ respectively compared with the same specimens in group (A) with side opening as shown in Figure18. The absorbed energy calculated as the area under the curve of load deflection. The calculated energy absorption of group (B) increased by about $67 \%, 60 \%, 64 \%, 76 \%$ and $82 \%$ for $0 \mathrm{~d}, 1.0 \mathrm{~d}, 1.5 \mathrm{~d}, 2 \mathrm{~d}$ and $2 \mathrm{~d}^{*}$ respectively compared with the same specimens in group (A) as shown in Figure19.

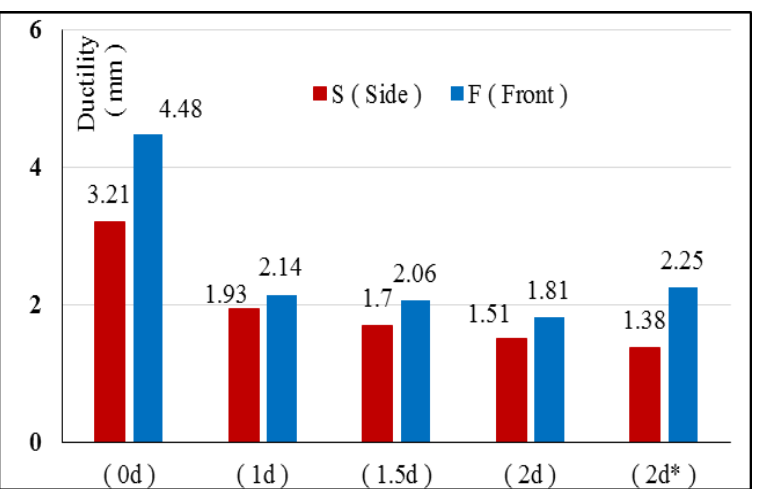

Figure 18. Ductility Values for Group (A, B).

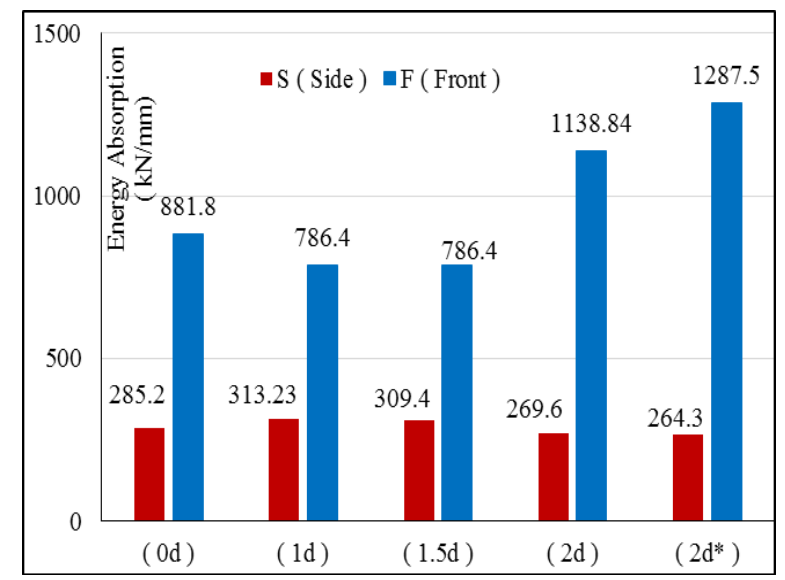

Figure 19. Energy Absorption Values for Group (A, B).

\section{CONCLUSION}

This research was conducted to investigate the enhancement of punching shear strength of the reinforced concrete edge column-flat slab connection with openings and strengthened with glass fiber reinforcing polymer. The research attempted to propose an innovative technique that could replace conventional methods of enhancing the punching shear strength of reinforced concrete slabs which, may be delay the punching shear failure and increase the load carrying capacity of the slabs.

Published By:

Blue Eyes Intelligence Engineering 
Based on the obtained results of the experimental work, the following can be concluded:

1- All tested specimens failed in a typical punching shear mode of failure.

2- The punching shear failure of the tested specimens indicated that the presence of openings in the vicinity of the column is not desirable especially those openings by the side of edge column.

3- Punching shear failure usually occurs at an angle of about 45 degrees on both sides of the column in the connection between the slab and the column; creating openings on the sides of the edge column more vulnerable to this type of failure.

4- Creating openings in flat slab beside the edge column should be approached with great caution and avoided if possible because it decreases the slab stiffness, ductility and strength to resist loads depending on the locations of these openings, in case of openings are of extreme necessity, it is recommended to be created in the front of the column not in the side.

5- The punching shear failure capacities of the test specimens with openings adjacent to RC column are about $62 \%$ and $35 \%$ smaller than the punching shear capacity of the reference test specimen for creating an opening at the side and front of the edge column respectively.

6- Strengthening with GFRP around the created opening beside the edge column in the tested specimens at each of compression and tension sides increase the punching shear capacity by about $48 \%$ and $50 \%$ for side and front opening respectively.

7- The stiffness of slab depend on the presence of the opening and its location, it decreased by about $22 \%$ and $8 \%$ for creating side and front opening beside the edge column respectively, this result indicated that creating an opening beside the edge column is the worst case.

\section{REFERENCES}

1. F. I. Ehab, "Effect of well-anchored stirrups on punching shear resistance in R.C. slab -column connection," M.Sc. thesis. Cairo University, Cairo, 1992.

2. A. Sherif, " Behaviour of Reinforced Concrete Flat Slabs," Ph.D. thesis. University of Calgary, Canada,1996.

3. A. Moussa, Some additional arrangements to increase the punching shear capacity of reinforced concrete slab-column connections. Paper presented at the meeting Specialty conference on the conceptual approach to structural design, Milan, Italy. 2003.

4. A. M. Abdelrahman, N.Z. Hassan, and A. M. Soliman, "Punching Shear Behaviour of Reinforced Concrete Slabs Using Steel Fibers in The Mix," HBRC Journal, vol. 14, no. 3, pp. 272-281, 2016. https://doi.org/10.1016/j.hbrcj.2016.11.001

5. N. Z. Hassan, M. A.Osman, A.M. Elhashimy, and H.K. Tantawy, "Enhancement of punching shear strength of flat slabs using shear-band reinforcement," HBRC Journal, vol. 14, no. 3, pp. 393-399, (2017). https://doi.org/10.1016/j.hbrcj.2017.11.003

6. C. Dulude, M. Hassan, E.A. Ahmed, and B. Benmokrane, "Punching Shear Behaviour of Flat Slabs Reinforced with Glass Fibre- Reinforced Polymer Bars," ACI Structural Journa, vol. 110, no. 5, pp. 723-733, 2013.

7. H. Eid, K.H. Riad, and A.H. Zaher, " Punching Shear Strength of Pre Stressed Flat Slab in Case of Near-Column Openings," World Applied Sciences Journal, vol. 32, no. 5, pp. 780-791, 2014. DOI: 10.5829/idosi.wasj.2014.32.05.14532
8. N.K. Oukaili,and T.S. Salman, "Punching Shear Strength of Reinforced Concrete Flat Plates with Openings," Journal of Engineering, vol. 20, no. 1, pp. 1-20, 2014.

9. C. Durucan, and Ö. Anil, "Effect of Opening Size and Location on the Punching Shear Behavior of Interior Slab-Column Connections Strengthened with CFRP Strips," Engineering Structures, vol. 105, pp. 22-36, 2015. https://doi.org/10.1016/j.engstruct.2015.09.033

10. A.S. Alfatlawi, and H.A. Abed, "CFRP Strengthening of Concrete Slabs with and without Openings," International Journal of Scientific \& Technology Research, vol. 4, no. 8, pp.132-147, 2015.

11. G.I Khaleel, and I.G Shaaban, \& K.M. Elsayedand, \& M.H. Makhlouf, "Strengthening of Reinforced Concrete Slab-Column Connection Subjected to Punching Shear with FRP Systems," IACSIT International Journal of Engineering and Technology, vol. 5, no. 6, pp. 657-661,2013. DOI: 10.7763/IJET.2013.V5.636

12. K.H. Tan, Strengthening of Flat Plates with an Opening Using FRP Systems. Paper presented at the meeting of APEFIS, Hokkaido University, Japan, 2012.

13. M.G. Elgendy, "Punching Shear Behaviour of Slab-Column Edge Connections Reinforced with Fibre-Reinforced Polymer (FRP) Composite Bars," M.Sc. thesis. University of Manitoba, Canada. 2014

14. K.M. Elsayed, N.N. Khalil, and M.I. Omar "Repair and Strengthening of R.C Flat Slab Connection with Edge Columns against Punching Shear," Advances in Research, vol. 8, no. 3, pp. 1-22, 2016.

\section{AUTHORS PROFILE}

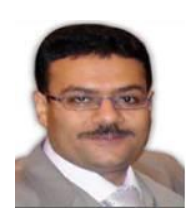

Waleed Abdallah Ali, is Assistant Professor in the Faculty of Engineering, Civil Department, Helwan University, Cairo, Egypt, where he has been a faculty member since 1997. He has about 20 years teaching experience for undergraduate students. He supervised many undergraduate projects and several master theses. He also supervised PHD students in Helwan University. His PHD studied "Behavior of Strengthened Reinforced Concrete Slabs in Fires" in March. 2008. His research interests lie in the area of structure analysis, reinforced concrete and Earthquake analysis. He has collaborated actively with researchers in other disciplines of civil engineering. He has attended in the International Conference on FRP Composites in Civil Engineering 2014 Vancouver, Canada | August 20-22, 2014 and the 8th International Conference on Fiber Reinforced Polymer (FRP) Composites in Civil Engineering (CICE2016), 14-16 December 2016, Hong Kong, China

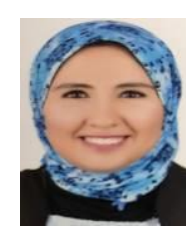

Eman Seleman Mohamed Gad, holds a master's degree in civil engineering from the Faculty of Engineering at Mataria, Civil Department, Helwan University, Cairo, Egypt. She had born in 25 Abril in year 1992 Egypt. She holds a Bachelor of Engineering from Teba Higher Institute of Engineering. She is Assistant teacher, Department of Civil Engineering, Cairo Higher Institute of Engineering in new Cairo from 2015till now. She teaches several courses like reinforced concrete design, structure analysis and material properties. She was a senior designer in consulting engineering office from 2014 to 2015. She holds many courses in the civil engineering field. 